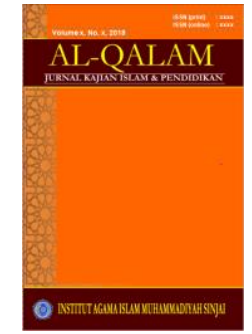

AL-QALAM

Jurnal Kajian Islam \& Pendidlikan

Volume 7, No. 1, 2015

ISSN (print) : 1858-4152

ISSN (online) : 2715-5684

Homepage : http://journal.al-qalam.iaims.ac.id

\title{
POTRET PENDIDIKAN MASA DINASTI UMAYYAH
}

\author{
Oleh : Muh. Anis*
}

$* * *$

\begin{abstract}
Abstrak
Sejarah pendidikan Islam pada hakekatnya sangat berkaitan erat dengan sejarah Islam. Periodesasi sejarah pendidikan Islam selalu selaras dengan periodesasi sejarah Islam itu sendiri. Oleh sebab itu, tulisan ini berusaha menguraikan secara global tentang potret pendidikan Islam masa dynasty Umayyah melalui tiga rumusan masalah yaitu: pola-pola pendidikan pada masa Dinasti Umayyah; tokoh-tokoh pendidikan pada masa itu, dan bentuk lembaga pendidikan pada masa itu dengan menggunakan pendekatan sejarah. Hasil dari ketiga rumusan tersebut menunjukkan bahwa Pola Pendidikan pada masa ini adalah menggunakan sistem desentrasi. Beberapa tokoh ulama-ulama termasyhur yang mewakili kota-kota Islam pada masa itu antara lain : Abdullah bin Umar di Makah, Abdullah bin Mas'ud di Kufah, Abdullah bin Abbas di Makah, dan Abdullah bin 'Amr bin 'Ash di Mesir. Madrasah atau lembaga pendidikan yang telah dibangun pada masa itu adalah Madrasah Makah, Madrasah Madinah, Madrasah Bashrah, Madrasah Kufah, Madrasah Damsyik (Damaskus), dan Madrasah Fustat di Mesir.
\end{abstract}

Kata Kunci: Pendidikan, Sejarah, Dinasti, Bani, Umayyah, Potret.

\section{PENDAHULUAN}

Dinasti Umayyah adalah kerajaan Islam pertama yang didirikan oleh Mu'awiyah ibn Abi Sofyān pada tahun $41 \mathrm{H} / 661 \mathrm{M}$. tahun ini disebut dengan 'Āmm al-Jamā'ah karena pada masa ini semua umat Islam sepakat atas ke-khalīfah-an Mu'awiyah dengan gelar Amīr al-Mu'minīn. Menurut catatan sejarah dinasti Umayyah ini terbagi menjadi dua periode, yaitu :

Pertama, Dinasti Umayyah I di Damaskus (41 H/661 M - 132 H/750 M), dinasti ini berkuasa kurang lebih selama 90 tahun dan mengalami pergantian pemimpin sebanyak 14 kali. Diantara khalīfah besar dinasti ini adalah Muawiyyah ibn Abī Sufyān (661-680 M), Abd al-Malik ibn Marwān (685-705 M), al-Walīd ibn Abdul Malik (705-715 M), 'Umar ibn Abd al-Azīz (717-720 M), dan

\footnotetext{
${ }^{*}$ Dosen STAI Muhammadiyah Sinjai
} 


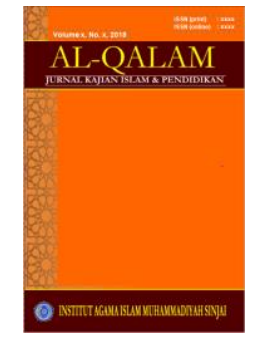

AL-QALAM

Jurnal Kajian Islam \& Pendidikan

Volume 7, No. 1, 2015

ISSN (print) : 1858-4152

ISSN (online) : 2715-5684

Homepage : http://journal.al-qalam.iaims.ac.id

Hisyām ibn Abd al-Malik (724-743 M).2 Sepeninggal Hisyām ibn Abd al-Malik, khalīfah-khalīfah Bani Umayyah yang tampil bukan hanya lemah tetapi juga bermoral buruk. Akhirnya, pada tahun 750 M, dinasti ini digulingkan oleh dinasti Abbasiyyah.

Kedua, Dinasti Umayyah II di Andalus/ Spanyol (755 - 1031 M), kerajaan Islam di Spanyol ini didirikan oleh Abd al-Rahman al- Dakhīl. Ketika Spanyol berada di bawah kekuasaan dinasti Umayyah II ini, umat Islam Spanyol mulai memperoleh kemajuan-kemajuan. Terutama pada masa kepemimpinan Abd al-Rämān al-Ausath, pendidikan Islam menunjukkan perkembangan yang sangat pesat. Hal ini desebabkan karena sang khalīfah sendiri terkenal sebagai penguasa yang cinta ilmu. Ia mengundang para ahli dari dunia Islam lainnya ke Spanyol sehingga kegiatan ilmu pengetahuan di sana menjadi kian semarak. Awal dari kehancuran dinasti Umayyah II di Spanyol ini bermula ketika Hisyām II (400 H/1009 M - 403 H/1013 M) naik tahta dalam usia 11 tahun. Pada tahun $981 \mathrm{M}$ khalīfah menunjuk Ibn Abī 'Āmir sebagai pemegang kekuasaan secara mutlak. Pada tahun $1009 \mathrm{M}$ khaliffah mengundurkan diri akibat beberapa kekacauan. Beberapa orang yang dicoba untuk menduduki jabatan itu tidak ada yang sanggup memperbaiki keadaan. Akhirnya pada tahun 1013 .Dewan Mentri menghapus jabatan khalïfah. Ketika itu Spanyol sudah terpecah menjadi beberapa negara kecil yang berpusat di kota-kota tertentu. ${ }^{1}$

Runtuhnya bani Umayyah yang pada kenyataanya telah membuka babak baru bagi perkembangan Islam secara keseluruhan pada dinasti bani Abbas, pada hakekatnya disebabkan dari perbedaan dua dinasti dalam memandang kepentingan negara. Dinasti Umayyah dengan corak Arabisme nampaknya lebih mementingkan ekspansi wilayah atau lazim disebut sebagai perluasan wilayah-wilayah Islam. Sedangkan dinasti Banī 'Abbasīyah, kepentingan Negara tidak tertumpu selalu pada perluasan wilayah, tetapi telah melebar kepada kepentingan-kepentingan pencapaian ilmuilmu pengetahuan dan peradaban. ${ }^{2}$

Dari urain tersebut di atas, pokok masalah yang dibahas dalam makalah ini adalah: Bagaimana pendidikan Islam pada masa Daulah Umayyah?, kemudian penulis membatasinya dengan beberapa sub masalah, yaitu: Bagaimana pola-pola pendidikan pada masa Dinasti Umayyah? Siapakah tokoh-tokoh pendidikan pada masa Bani Umayyah?, Bagaimana bentuk Madrasah/universitas pada masa Bani Umayyah?.

\section{PEMBAHASAN}

\section{A. Pola Pendidikan Islam Pada Priode Dinasti Umayyah}

Sejarah pendidikan Islam pada hakekatnya sangat berkaitan erat dengan sejarah Islam. Periodesasi pendidikan Islam selalu berada dalam periode sejarah Islam itu sendiri. Secara garis besarnya Harun Nasution membagi sejarah Islam ke dalam tiga periode. Yaitu periode Klasik, Pertengahan dan Modern. Kemudian perinciannya dapat dibagi lima periode, yaitu: Periode Nabi

\footnotetext{
${ }^{1}$ Hasan Ibrahim, Sejarah dan Kebudayaan Islam (Jakarta: Kalam Mulia 2001), h. 49

2 Harun Nasution, Islam Ditinjau dari Berbagai Aspeknya, jilid I, (Jakart: UI Press, 1984), h. 70
} 


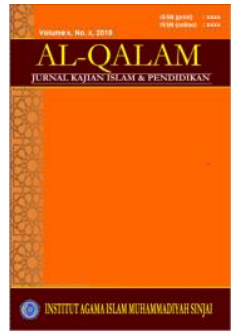

AL-QALAM

Jurnal Kajian Islam \& Pendidikan

Volume 7, No. 1, 2015

ISSN (print) : 1858-4152

ISSN (online) : 2715-5684

Homepage : http://journal.al-qalam.iaims.ac.id

Muhammad SAW (571-632 M), periode Khulafä' al-Rasyidīn (632-661 M), periode kekuasaan Daulah Umayyah (661-750 M), periode kekuasaan Abbasiyah (750-1250 M) dan periode jatuhnya kekuasaan khalīfah di Baghdad (1250-sekarang). ${ }^{3}$ Dalam makalah ini penulis membahas tentang pola pendidikan Islam pada periode Dinasti Umayyah. Kekuasaan Bani Umayyah berumur kurang lebih 90 tahun. Ibu kota negara dipindahkan Muawiyyah dari Madinah ke Damaskus, tempat ia berkuasa sebagai gubernur sebelumnya. Mu'āwiyah Ibn Abī Sufyān adalah pendiri Dinasti Umayyah yang berasal dari suku Quraisy yang merupakan keturunan Umayyah bin 'Abd Syams yang mendeklarasikan diri sebagai khalïfah pertama dari tahun 661-750 M, nama lengkapnya ialah Mu'āwiyah bin Abī H $\left\{\right.$ arb bin Umayyah bin 'Abdi Syams bin 'Abdi Manāf. ${ }^{4}$

Setelah Muawwiyah diangkat menjadi khalīfah ia merubah sistem pemerintahan dari Teodemokratis menjadi Monarki (Kerajaan/Dinasti) dan sekaligus memindahkan Ibu Kota Negara dari Kota Madinah ke Kota Damaskus. Muawwiyah lahir 4 tahun menjelang Nabi Muhammad saw. menjalankan Dakwah Islam di Kota Makkah, ia beriman dalam usia muda dan ikut hijrah bersama Nabi ke Yatsrīb. Di samping itu termasuk salah seorang pencatat wahyu, dan ambil bagian dalam beberapa peperangan bersama Nabi. ${ }^{5}$ Dari uraian ini maka dapat diketahui bahwa pengagas atau tokoh pendiri dinasti ini adalah $\mathrm{Mu}$ 'awiyah bin Ab̄̄ Sofyan dan nama dinastinya diambil dari dari nama kakek mereka yaitu Umayyah bin 'Abdi Manāf.

Pada dinasti Umayyah perluasan daerah Islam sangat luas sampai ke Timur dan Barat. Begitu juga dengan daerah Selatan yang merupakan tambahan dari Daerah Islam di zaman Khulafä' alRāsyidīn yaitu: Hijāz, Syiria, 'Irāq, Persia dan Mesir. Seiring dengan itu pendidikan pada priode Danasti Umayyah telah ada beberapa lembaga seperti: Kuttāb, Masjid dan Majelis Sastra. Materi yang diajarkan bertingkat-tingkat dan bermacam-macam. Metode pengajarannya pun tidak sama. Sehingga melahirkan beberapa pakar ilmuan dalam berbagai bidang tertentu. ${ }^{6}$

Pada masa dinasti Umayyah pola pendidikan bersifat desentralisasi. Desentralisasi artinya pendidikan tidak hanya terpusat di ibu kota Negara saja tetapi sudah dikembangkan secara otonom di daerah yang telah dikuasai seiring dengan ekspansi teritorial, Sistem pendidikan ketika itu belum memiliki tingkatan dan standar umur. ${ }^{7}$ Kajian ilmu yang ada pada periode ini berpusat di Damaskus, Kūfah, Makkah, Madīnah, Mesir, Cordova dan beberapa kota lainnya, seperti: Bashrah dan Kūfah (Irak), Damsyik dan Palestina (Syam), Fusthāth (Mesir). Diantara ilmu-ilmu yang dikembangkannya, yaitu: kedokteran, filsafat, astronomi atau perbintangan, ilmu pasti, sastra, seni baik itu seni bangunan, seni rupa, maupun seni suara. ${ }^{8}$ Menurut uruaian di atas berarti pola pendidikan Islam pada periode

\footnotetext{
${ }^{3}$ Zuhairini, Sejarah Pendidikan Islam ( Jakarta : Bumi Aksara, 1992), h. 7

${ }^{4}$ Dewan Redaksi, Ensiklopedi Islam, (Jakarta, Ikhtiar Baru Van Hoeve, 1967), cet ke-2

${ }^{5}$ Yusuf Syu'aib, Sejarah Daulah Umayyah 1,( Jakarta, Bulan Bintang, 1997), h. 13

${ }^{6}$ Hasan Langgulung, Pendidikan Islam Menghadapi Abad-21, (Jakarta, Pustaka Al Husna, 1980), h. 17

${ }^{7}$ http://karyaulama.blogspot.com/2008/04/pola-pendidikan-Islam-periode-dinasti.html

${ }^{8}$ http://akitephos.wordpress.com/sejarah-pendidikan-Islam/
} 


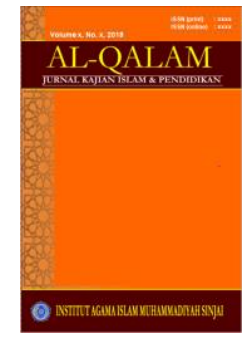

AL-QALAM

Jurnal Kajian Islam \& Pendidikan

Volume 7, No. 1, 2015

ISSN (print) : 1858-4152

ISSN (online) : 2715-5684

Homepage : http://journal.al-qalam.iaims.ac.id

Dinasti Umayyah telah berkembang bila dibandingkan pada masa Khulafā al-Rasyidīn yang ditandai dengan semaraknya kegiatan ilmiah di masjid-masjid dan berkembangnya Kuttāb serta Majelis Sastra.

Dengan demikian, tempat pendidikan pada periode Dinasti Umayyah adalah:

\section{Kuttāb}

Kuttāb atau Maktab berasal dari kata dasar kataba yang berarti menulis atau tempat menulis, jadi Kuttāb adalah tempat belajar menulis. Kuttāb merupakan tempat anak-anak belajar menulis dan membaca, menghafal Al-Quran serta belajar pokok-pokok ajaran Islam. ${ }^{9}$

Adapun cara yang dilakukan oleh pendidik disamping mengajarkan Al-Quran mereka juga belajar menulis dan tata bahasa serta tulisan. Perhatian mereka bukan tertumpu mengajarkan AlQuran semata dengan mengabaikan pelajaran yang lain, akan tetapi perhatian mereka pada pelajaran sangat pesat. Al-Quran dipakai sebagai bahasa bacaan untuk belajar membaca, kemudian dipilih ayat-ayat yang akan ditulis untuk dipelajari. Disamping belajar menulis dan membaca murid-murid juga mempelajari tata bahasa Arab, cerita-cerita Nabi, Hadis dan pokok agama. ${ }^{10}$

Kalau dilihat di dalam sejarah pendidikan Islam pada awalnya dikenal dua bentuk kuttāb, yaitu:

a. Kuttāb berfungsi sebagai tempat pendidikan yang memfokuskan pada tulis baca.

b. Kuttāb tempat pendidikan yang mengajarkan Al-Quran dan dasar-dasar keagamaan. ${ }^{11}$

Ilmu-ilmu yang diajarkan pada kuttāb pada mula-mulanya adalah dalam keadaan sederhana, yaitu:

1) Belajar membaca dan menulis

2) Membaca Al-Qur'an dan menghafalnya

3) Belajar pokok-pokok agama Islam, seperti cara wudhu, shalat, puasa dan sebagainya.

Ilmu-ilmu yang diajarkan pada tingkat menengah dan tinggi terdiri dari:

a) Al-Qur'an dan tafsirannya.

b) Hadis dan kodifikasinya.

c) Fiqih (Tasyrī').

Peserta didik dalam kuttāb adalah anak-anak tidak dibatasi, baik miskin maupun kaya. Para guru tidak membedakan murid-murid mereka, bahkan ada sebagian anak miskin yang belajar di kuttāb memperoleh pakaian dan makanan secara cuma-cuma. Anak-anak perempuan pun memperoleh hak yang sama dengan anak-anak laki-laki dalam belajar. Namun tidak tertutup

\footnotetext{
${ }^{9}$ Mahmud. Yunus, Sejarah Pendidikan Islam, (Jakarta, PT. Hida Karya Agung, 1981), h. 39.

${ }^{10}$ Zuhairini, Sejarah Pendidikan Islam, h. 47

${ }^{11}$ lbid, h.8
} 


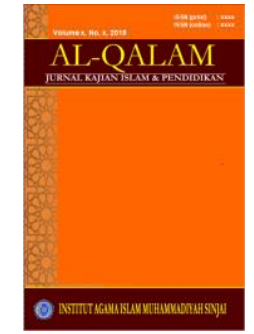

AL-QALAM

Jurnal Kajian Islam \& Pendidikan

Volume 7, No. 1, 2015

ISSN (print) : 1858-4152

ISSN (online) : 2715-5684

Homepage : http://journal.al-qalam.iaims.ac.id

kemungkinan bagi orang yang mampu mendidik anak-anak mereka di tempat khusus yang mereka inginkan dengan guru yang khusus pula seperti: Hajjāj ibn Yūsuf yang pernah menjadi guru bagi putra Sulaimān Nasūh seorang Menteri dari khalīfah Abdul Malik ibn Marwan. ${ }^{12}$ Hal inilah seharusnya pendidikan, tidak membeda-bedakan antara satu siswa dengan siswa lain.

\section{Masjid}

Setelah pelajaran masa kanak-kanak di kuttāb selesai, mereka melanjutkan pendidikan ke tingkat menengah yang dilakukan di masjid. Peranan Masjid sebagai pusat pendidikan dan pengajaran senantiasa terbuka lebar bagi setiap orang yang merasa dirinya tetap dan mampu untuk memberikan atau mengajarkan ilmunya kepada orang-orang yang haus akan ilmu pengetahuan.

Pada masa Dinasti Umayyah, Masjid merupakan tempat pendidikan tingkat menengah dan tingkat tinggi setelah kuttāb. Pelajaran yang diajarkan meliputi Al-Quran, Tafsir, Hadis dan Fiqih. Juga diajarkan kesusasteraan, sajak, gramatika bahasa, ilmu hitung dan ilmu perbintangan. ${ }^{13}$

Diantara jasa besar pada periode Dinasti Umayyah dalam perkembangan ilmu pengetahuan adalah menjadikan Masjid sebagai pusat aktivitas ilmiah termasuk sya'ir. Sejarah bangsa terdahulu diskusi dan akidah. Pada periode ini juga didirikan Masjid ke seluruh pelosok daerah Islam. Masjid Nabawi di Madinah dan Masjid al-Haram di Makkah selalu menjadi tumpuan penuntut ilmu di seluruh dunia Islam, dan tampak juga pada pemerintahan al-Walīd ibn Abdul Malik 707-714 M yang merupakan Universitas terbesar dan juga didirikan Masjid Zaitunnah di Tunisia yang dianggap Universitas tertua sampai sekarang. Pada Dinasti Umayyah ini, masjid sebagai tempat pendidikan terdiri dari dua tingkat yaitu: tingkat menengah dan tingkat tinggi. Pada tingkat menengah guru belumlah ulama besar sedangkan pada tingkat tinggi gurunya adalah ulama yang dalam ilmunya dan masyhur kealiman dan keahliannya. Umumnya pelajaran yang diberikan guru kepada murid-murid seorang demi seorang, baik di kuttāb atau di Masjid tingkat menengah. Sedangkan pada tingkat pelajaran yang diberikan oleh guru adalah dalam satu Halaqah yang dihadiri oleh pelajar bersama-sama. ${ }^{14}$

\section{Majelis Sastra}

Majelis sastra merupakan balai pertemuan yang disiapkan oleh khalifah dihiasi dengan hiasan yang indah, hanya diperuntukkan bagi sastrawan dan ulama terkemuka. Menurut

\footnotetext{
${ }^{12}$ Asma Hasan Fahmi, Mabadi'at Tarbiyyah Al Islamiyyah, diterjemahkan oleh Mukhtar Yahya dan Sanusi Latif, (Jakarta, Bulan Bintang, tth), h. 47

13 http://karyaulama.blogspot.com/2008/04/pola-pendidikan-Islam-periode-dinasti.html

14 Haidar Putra Daulay, Pendidikan Islam Dalam Lintasan Sejarah, (Jakarta Kencana Prenada Media Group, 2013), hal. 61
} 


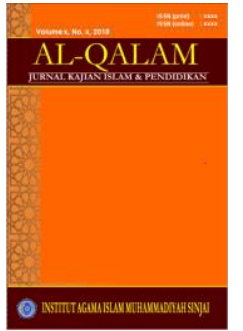

AL-QALAM

Jurnal Kajian Islam \& Pendidlikan

Volume 7, No. 1, 2015

ISSN (print) : 1858-4152

ISSN (online) : 2715-5684

Homepage : http://journal.al-qalam.iaims.ac.id

Muhammad 'Athiyyah al-Abrasī, balai-balai pertemuan tersebut mempunyai tradisi khusus yang mesti diindahkan seseorang yang masuk ketika khaliffah hadir, mestilah berpakaian necis, bersih dan rapi, duduk di tempat yang sepantasnya, tidak tertawa terbahak-bahak, tidak meludah, tidak mengingus dan tidak menjawab kecuali bila ditanya. Ia tidak boleh bersuara keras dan harus bertutur kata dengan sopan dan memberi kesempatan pada sipembicara menjelaskan pembicaraannya serta menghindari penggunaan kata kasar dan tawa terbahak-bahak. Dalam balai pertemuan seperti ini disediakan pokok persoalan untuk dibicarakan, didiskusikan dan diperdebatkan. ${ }^{15}$

Majelis sastra merupakan tempat berdiskusi membahas masalah kesusasteraan dan juga sebagai tempat berdiskusi mengenai urusan politik. Perhatian penguasa Ummayyah sangat besar pada pencatatan kaidah-kaidah nahwu, pemakaian Bahasa Arab dan mengumpulkan Syair-syair Arab dalam bidang syarī'ah, kitābah dan berkembangnya semi prosa.

\section{Pendidikan Istana}

yaitu pendidikan yang diselenggarakan dan diperuntukkan khusus bagi anak-anak khaliffah dan para pejabat pemerintahan. Kurikulum pada pendidikan istana diarahkan untuk memperoleh kecakapan memegang kendali pemerintahan atau hal-hal yang ada sangkut pautnya dengan keperluan dan kebutuhan pemerintah, maka kurikulumnya diatur oleh guru dan orang tua murid. ${ }^{16}$

\section{Pendidikan Bädiah}

yaitu tempat belajar bahasa Arab yang fasih dan murni. Hal ini terjadi ketika khalīfah Abdul Malik ibn Marwān memprogramkan Arabisasi maka muncul istilah Bādiah, yaitu dusun badui di Padang Sahara mereka masih fasih dan murni sesuai dengan kaidah bahasa Arab tersebut. Sehingga banyak khalïfah yang mengirimkan anaknya ke Bädiah untuk belajar bahasa Arab bahkan ulama juga pergi ke sana di antaranya adalah al-Khalīl ibn Ahmad. ${ }^{17}$

Periode Dinasti Umayyah pada bidang pendidikan, adalah menekankan ciri ilmiah pada Masjid sehingga menjadi pusat perkembangan ilmu pengetahuan tinggi dalam masyarakat Islam. Dengan penekanan ini di Masjid diajarkan beberapa macam ilmu, diantaranya syair, sastra dan ilmu lainnya. Dengan demikian periode antara permulaan abad ke dua hijrah sampai akhir abad ketiga hijrah merupakan zaman pendidikan Masjid yang paling cemerlang.

Jadi sistem pendidikan Islam ketika itu masih berjalan secara alamiah karena kondisi ketika itu diwarnai oleh kepentingan politis dan golongan. Pada umumnya, gerakan penerjemahan ini terbatas keadaan orang-orang tertentu dan atas usaha sendiri, bukan atas

\footnotetext{
${ }^{15}$ http://karyaulama.blogspot.com/2008/04/pola-pendidikan-Islam-periode-dinasti.html

${ }^{16}$ http://karyaulama.blogspot.com/2008/04/pola-pendidikan-Islam-periode-dinasti.html

${ }^{17}$ Yusuf Syu'aib, Sejarah Daulah Umayyah 1, h.
} 


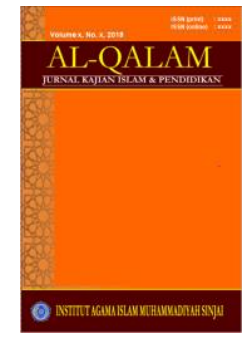

AL-QALAM

Jurnal Kajian Islam \& Pendidikan

Volume 7, No. 1, 2015

ISSN (print) : 1858-4152

ISSN (online) : 2715-5684

Homepage : http://journal.al-qalam.iaims.ac.id

dorongan negara dan tidak dilembagakan. Franz Rosenthal, dia menyatakan bahwa orang yang pertama kali melakukan penerjemahan ini adalah Khalīd ibn Yazīd cucu dari Muawwiyah. ${ }^{18}$

Selain kemajuan seperti di atas ilmu pengetahuan yang berkembang pada masa ini adalah:

a. Ilmu agama, seperti: Al-Qur'an, Hadis, dan Fiqih. Proses pembukuan Hadis terjadi pada masa Khalīfah 'Umar ibn Abd al-Azīz sejak saat itulah hadis mengalami perkembangan pesat.

b. Ilmu sejarah dan geografi, yaitu segala ilmu yang membahas tentang perjalanan hidup, kisah, dan riwayat. Ubaid Ibn Sāriyah al-Jurhumī berhasil menulis berbagai peristiwa sejarah.

c. Ilmu pengetahuan bidang bahasa, yaitu segla ilmu yang mempelajari bahasa, nahwu, sharaf, dan lain-lain.

d. Bidang filsafat, yaitu segala ilmu yang pada umumnya berasal dari bangsa asing, seperti ilmu mantik, kimia, astronomi, ilmu hitung dan ilmu yang berhubungan dengan itu, serta ilmu kedokteran. ${ }^{19}$

\section{B. Tokoh-Tokoh Pendidikan Pada Masa Bani Umayyah}

Tokoh-tokoh pendidikan pada masa Bani Umayyah terdiri dari ulama-ulama yang menguasai bidangnya masing-masing seperti dalam bidang tafsir, Hadis, dan Fiqh. Selain para ulama juga ada ahli bahasa/sastra.

\section{Ulama-ulama tabi'in ahli tafsir}

Yaitu: Mujāhid, 'Athā' bin Abī Rabāhn, 'Ikrimah, Sa'̄̄d bin Jubair, Masrūq bin al-Ajda', Qatādah. Pada masa tabi' in tafsir Al-Qur'an bertambah luas dengan memasukkan Israiliyat dan Nasraniyat, karena banyak orang-orang Yahudi dan Nasrani memeluk agama Islam. Di antara mereka yang termasyhur: Ka'b al-Aㅌbār, Wahb bin Munabbih, Abdullah bin 'Abbas, Ibn Juraij. ${ }^{20}$

\section{Ulama-ulama Hadis}

Kitab bacaan satu-satunya ialah al-Qur'an. Sedangkan hadis-hadis belumlah dibukukan. Hadis-hadis hanya diriwayatkan dari mulut ke mulut. Dari mulut guru ke mulut muridnya, yaitu dari hafalan uru diberikannya kepada murid, sehingga menjdi hafalan murid pula dan begitulah seterusnya. Setengah sahabat dan pelajar-pelajar ada yang mencatat Hadis-Hadis itu dalam buku catatannya, tetapi belumlah berupa buku menurut istillah kita sekarang. Ulama-ulama sahabat yang banyak meriwayatkan hadis-hadis ialah: Abū Hurairah (5374 Hadis), 'Āisyah (2210 Hadis),

\footnotetext{
${ }^{18}$ Suwedi, Sejarah Pemikiran Pendidikan Islam, Jakarta, PT. Raja Grafindo Persada, 2004, h. 16

${ }^{19}$ http://akitephos.wordpress.com/sejarah-pendidikan-Islam/

${ }^{20}$ Hasan Ibrahim, Sejarah dan Kebudayaan Islam, h. 402.
} 


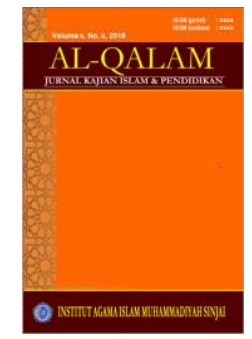

AL-QALAM

Jurnal Kajian Islam \& Pendidikan

Volume 7, No. 1, 2015

ISSN (print) : 1858-4152

ISSN (online) : 2715-5684

Homepage : http://journal.al-qalam.iaims.ac.id

Abdullah bin 'Umar ( \pm 2210 Hadis), Abdullah bin 'Abbās ( \pm 1500 Hadis), Jābir bin Abdullah $\left( \pm 1500\right.$ Hadis), Anas bin Mālik ( \pm 2210 Hadis). ${ }^{21}$

\section{Ulama-ulama ahli Fiqh}

Ulama-ulama tabi'in Fiqih pada masa bani Umayyah di antaranya adalah:, Syuraih bin alHārits, 'Alqamah bin Qais, Masrūq bin al-Ajda', al-Aswad bin Yazid kemudian diikuti oleh murid-murid mereka, yaitu: Ibrāhīm al-Nakha'̄̄ (wafat tahun 95 H) dan 'Āmir bin Syarahbīl alSya'bī (wafat tahun $104 \mathrm{H}$ ). sesudah itu digantikan oleh $\mathrm{H}\{$ ammād bin Ab̄̄ Sulaimān (wafat tahubn $120 \mathrm{H}$ ), guru dari Abū Hanīfah.

\section{Madrasah/Universitas Pada Masa Bani Umayyah}

Perluasan negara Islam bukanlah perluasan dengan merobohkan dan menghancurkan, bahkan perluasan dengan teratur diikuti oleh ulama-ulama dan guru-guru agama yang turut bersama-sama tentara Islam. Pusat pendidikan telah tersebar di kota-kota besar sebagai berikut: di kota Makkah dan Madinah (H\{ijāz), di kota Basrah dan Kūfah ('Irāk), di kota Damsyik dan Palestina (Syām), di kota Fusthāt (Mesir). Madrasah-madrasah yang ada pada masa Bani Umayyah adalah sebagai berikut:

\section{Madrasah Makkah}

Guru pertama yang mengajar di Makkah, sesudah penduduk Makkah takluk, ialah Mu'āzl bin Jabal. Kemudian Abdullah bin 'AbbĀs, selanjutnya ia mengajarkan tafsir, fiqih, dan sastra. Abdullah bin 'Abbās adalah pembangun madrasah Makkah, selanjutnya beliau digantikan oleh muridnya dari kalangan tābi' in seperti Mujāhid dan 'Athā bin Abī RabāH. Mujahid termasyhur dalam bidan tafsir, 'athak dalam bidang fikih, selanjutnya mereka digantikan oleh Sufyan bin 'Uyainah dan Muslim bin Khālid, keduanya adalah guru Imam Syafi'ī yang pertama.

\section{Madrasah Madīnah}

Madrasah Madinah lebih termasyur dan lebih dalam ilmunya, karena di sanalah tempat tinggal sahabat-sahabat nabi. Berarti disana banyak terdapat ulama-ulama terkemuka seperti Zaid bin S|ābit dan Abdullah bin 'Umar, dari kalangan tābi'īn terkenal Sa'īd bin Musayyab dan 'Urwah bin al-Zubair bin al-'Awwam

\section{Madrasah Bashrah}

Ulama sahabat yang termasyur di Bashrah ialah Abū Mūsa al-Asy'arī dan Anas bin Mālik. Abū Mūsa al-Asy'arī adalah seorang ahli fiqih dan ahli Hadis, serta ahli Al-Qur'an dan Tafsir. Sedangkan Anas bin Mālik termasyhur dalam ilmu hadis. Al-Hasan Basry sebagai ahli fiqh, juga ahli pidato dan kisah, ahli fikir dan ahli tasawuf. Ia bukan saja mengajarkan ilmu-ilmu agama kepada pelajar-pelajar, bahkan juga mengajar orang banyak dengan mengadakan kisahkisah di masjid Basrah.

\section{Madrasah Kūfah}

\footnotetext{
${ }^{21}$ Hasan Ibrahim, Sejarah dan Kebudayaan Islam, h. 403
} 


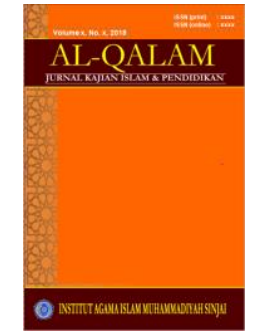

AL-QALAM

Jurnal Kajian Islam \& Pendidikan

Volume 7, No. 1, 2015

ISSN (print) : 1858-4152

ISSN (online) : 2715-5684

Homepage : http://journal.al-qalam.iaims.ac.id

Madrasah Ibn Mas'ūd di Kūfah melahirkan enam orang ulama besar, yaitu: 'Alqamah, al-

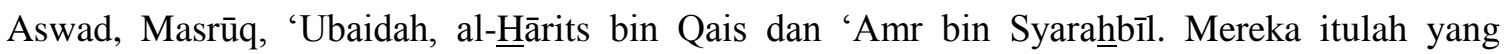
menggantikan Abdullah bin Mas'ūd menjadi guru di Kūfah. Ulama Kūfah, bukan saja belajar kepada Abdullah bin Mas'ūd menjadi guru di Kūfah. Ulama Kūfah, bukan saja belajar kepada Abdullah bin Mas'ūd. Bahkan mereka pergi ke Madinah.

\section{Madrasah Syām}

Setelah negeri Syam (Siriya) menjadi sebagian Negara Islam dan penduduknya banyak memeluk agama Islam. Maka negeri Syam menjadi perhatian para Khilafah. Madrasah itu melahirkan imam penduduk Syam, yaitu Abdurrahman al-'Auza'̄̄ yang sederajat ilmunya dengan

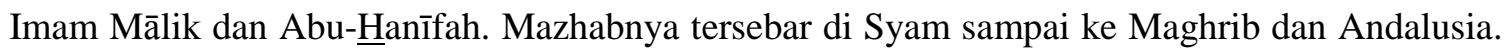
Tetapi kemudian mazhabnya itu lenyap, karena besar pengaruh mazhab Syafi' 'ì dan Mālikī.

\section{Madrasah Fusthāt (Mesir)}

Setelah Mesir menjadi negara Islam ia menjadi pusat ilmu-ilmu agama. Ulama yang mulamula mendirikan madrasah di Mesir ialah Abdullah bin 'Amr bin al-'Āsh, yaitu di Fusthāt (Mesir lama). Ia ahli hadis dengan arti kata yang sebenarnya. Karena ia bukan saja menghafal hadis-hadis yang didengarnya dari Nabi Saw., melainkan juga dituliskannya dalam buku catatan, sehingga ia tidak lupa atau khilaf meriwayatkan hadis-hadis itu kepada murid-muridnya. Dengan demikian dunia ilmu pengetahuan tersebar di seluruh kota-kota di Negara Islam. ${ }^{22}$

Berdasarkan uraian di atas dapat dilihat bahwa para sahabat Nabi saw. Tersebar keberbagai kota-kota Islam dan disana mereka menjadi ulama yang melahirkan generasi-generasi berikutnya sehingga estafet keilmuan Islam bergulir dari satu generasi ke generasi berikutnya.

\section{KESIMPULAN}

Dari uraian diatas, maka dapat dipahami bahwa pada masa Dinasti Umayah telah terjadi perubahan sistem pemerintahan, yakni dari Theo Demokrasi menjadi Monarki (Kerajaan/Dinasti). Ini tidak terlepas dari pengaruh situasi politik pada saat itu. Pendidikan Islam sebagai suatu sistem di suatu wilayah, tentunya tidak dapat dipisahkan dari situasi politik di wilayah tersebut. Berubahubahnya kebijakan politik membuat berubah-ubahnya kebijaksanaan penguasa terhadap pelaksanaan pendidikan Islam.

Pola Pendidikan pada masa ini adalah menggunakan sistem Desentrasi artinya pendidikan tidak hanya terpusat di ibu kota Negara saja tetapi sudah dikembangkan secara otonom di daerah yang telah dikuasai seiring dengan ekspansi territorial. Sistem pendidikan ketika itu belum memiliki tingkatan dan standar umur. Kajian ilmu yang ada pada periode ini berpusat di Damaskus, Kufah, Makkah, Madinah, Mesir, Cordova dan beberapa kota lainnya, seperti: Basrah dan Kuffah (Irak), Damsyik dan Palestina (Syam), Fistat (Mesir). Diantara ilmu-ilmu yang dikembangkannya, yaitu:

22 Haidar Putra Daulay, Pendidikan Islam Dalam Lintasan Sejarah, h. 65-67 


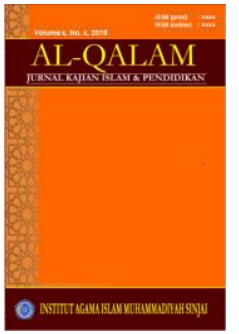

AL-QALAM

Jurnal Kajian Islam \& Pendidlikan

Volume 7, No. 1, 2015

ISSN (print) : 1858-4152

ISSN (online) : 2715-5684

Homepage : http://journal.al-qalam.iaims.ac.id

kedokteran, filsafat, astronomi atau perbintangan, ilmu pasti, sastra, seni baik itu seni bangunan, seni rupa, maupun seni suara

Beberapa tokoh ulama-ulama termasyhur yang mewakili kota-kota Islam pada masa itu antara lain : Abdullah bin Umar di Makah, Abdullah bin Mas'ud di Kufah, Abdullah bin Abbas di Makah, dan Abdullah bin 'amr bin 'ash di Mesir.

Madrasah atau lembaga pendidikan yang telah dibangun pada masa itu adalah Madrasah Makah, Madrasah Madinah, Madrasah Bashrah, Madrasah Kufah, Madrasah Damsyik (Damaskus), dan Madrasah Fustat di Mesir. 


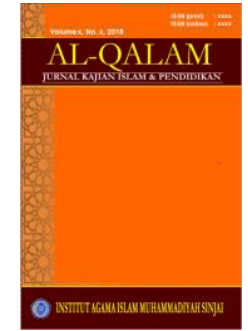

AL-QALAM

Jurnal Kajian Islam \& Pendidlikan

Volume 7, No. 1, 2015

ISSN (print) : 1858-4152

ISSN (online) : 2715-5684

Homepage : http://journal.al-qalam.iaims.ac.id

\section{DAFTAR PUSTAKA}

al-Abrasi, Athiyya. Tarbìyah al-Islāmīyah, Terjemahan Bustami A. Ghani, Jakarta: Bulan Bintang, 1993.

Chalil, Munawar. Empat Biografi Imam Mazhab, Jakarta: Bulan Bintang, 1989.

Daulay, Haidar Putra. Pendidikan Islam dalam Lintasan Sejarah, Jakarta: Kencana Prenada Media, 2005.

Dewan Redaksi. Ensiklopedi Islam, Jakarta: Ikhtiar Baru Van Hoeve, 1967.

Fahmi, Asma Hasan. Mabādi' al-Tarbìyah al-Islāmīyah, diterjemahkan oleh Mukhtar Yahya dan Sanusi Latif, Jakarta: Bulan Bintang, t.th.

http://akitephos.wordpress.com/sejarah-pendidikan-Islam.

http://akitephos.wordpress.com/sejarah-pendidikan-Islam/

http://karyaulama.blogspot.com/2008/04/pola-pendidikan-Islam-periode-dinasti.html

http://karyaulama.blogspot.com/2008/04/pola-pendidikan-Islam-periode-dinasti.html

Langgulung, Hasan. Pendidikan Islam Menghadapi Abad-21, Jakarta: Pustaka Al-Husna, 1980.

Nizar, Samsul. Sejarah Pergolakan Pemikiran Pendidikan Islam, Jakarta: Cuputat Press, 2005.

Suwedi. Sejarah Pemikiran Pendidikan Islam, Jakarta, PT. Raja Grafindo Persada, 2004.

Syu'aib, Yusuf. Sejarah Daulah Umayyah. Jld. 1, Jakarta, Bulan Bintang, 1997.

Yunus, Mahmud. Sejarah Pendidikan Islam, Jakarta, PT. Hida Karya Agung, 1981.

Zuhairini. Sejarah Pendidikan Islam, Jakarta : Bumi Aksara, 1992. 